\title{
Passive Cooling Solutions to Improve Thermal Comfort in Polish Dwellings
}

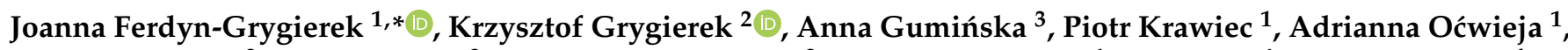 \\ Robert Poloczek $^{2}$, Julia Szkarłat ${ }^{3}$, Aleksandra Zawartka ${ }^{3}$, Daria Zobczyńska ${ }^{1}$ and Daria Żukowska-Tejsen ${ }^{4}$ \\ 1 Faculty of Energy and Environmental Engineering, Silesian University of Technology, Konarskiego 20, \\ 44-100 Gliwice, Poland; piotkra663@student.polsl.pl (P.K.); adriocw768@student.polsl.pl (A.O.); \\ darizob403@student.polsl.pl (D.Z.) \\ 2 Faculty of Civil Engineering, Silesian University of Technology, Akademicka 5, 44-100 Gliwice, Poland; \\ krzysztof.grygierek@polsl.pl (K.G.); robepol868@student.polsl.pl (R.P.) \\ 3 Faculty of Architecture, Silesian University of Technology, Akademicka 7, 44-100 Gliwice, Poland; \\ anna.guminska@polsl.pl (A.G.); juliszk256@student.polsl.pl (J.S.); alekzaw660@student.polsl.pl (A.Z.) \\ 4 Department of Civil Engineering, Technical University of Denmark, Brovej 118, \\ DK-2800 Kgs. Lyngby, Denmark; d.zukowska.tejsen@gmail.com \\ * Correspondence: Joanna.Ferdyn-Grygierek@polsl.pl; Tel.: +48-32-237-29-12
}

check for

updates

Citation: Ferdyn-Grygierek, J.;

Grygierek, K.; Gumińska, A.;

Krawiec, P.; Oćwieja, A.; Poloczek, R.;

Szkarłat, J.; Zawartka, A.;

Zobczyńska, D.; Żukowska-Tejsen, D. Passive Cooling Solutions to Improve Thermal Comfort in Polish Dwellings. Energies 2021, 14, 3648. https:// doi.org/10.3390/en14123648

Academic Editor: Patrick Phelan

Received: 26 May 2021

Accepted: 15 June 2021

Published: 18 June 2021

Publisher's Note: MDPI stays neutral with regard to jurisdictional claims in published maps and institutional affiliations.

Copyright: (C) 2021 by the authors. Licensee MDPI, Basel, Switzerland. This article is an open access article distributed under the terms and conditions of the Creative Commons Attribution (CC BY) license (https:/ / creativecommons.org/licenses/by/ $4.0 /)$.

\begin{abstract}
The household sector in Poland consumes more than $25 \%$ of final energy. At the same time, residents reported dissatisfaction with the thermal conditions during the summer months. This paper details the search for passive and energy-efficient solutions to improve thermal comfort in Polish dwellings. A five-story, multi-family building was selected for this research. Analyses were conducted in apartments located on the top two floors using EnergyPlus (for thermal calculations) and CONTAM (for air exchange calculations) simulation programs for current and future climatic conditions. The stochastic behavior of people when opening windows and automatically controlled systems supplying external air to the building was considered. Airing the apartments by opening windows increased the heating demand but reduced the number of thermal discomfort hours by over $90 \%$. The degree of airing by opening windows depends on residents opening their windows; therefore, a mechanical supply of external air controlled by both internal and external temperatures was proposed and tested.
\end{abstract}

Keywords: thermal comfort; heat demand; dwelling; ventilation; ventilative cooling

\section{Introduction}

Current trends in the construction sector seek to improve building energy efficiencies. The housing sector consumes up to $25 \%$ of final energy [1]. Existing multi-family buildings built during the 1960s comprise a large part of the housing stock in Poland $(1,774,838$ apartments) and account for approximately $40 \%$ of the housing stock that generates energy losses [2]. These buildings were erected according to different technical requirements and are currently undergoing various thermal modernizations and/or upgrades. In Poland and other countries of Central and Northern Europe, current modernization practices normally involve increasing the insulation thickness. This led to thermal improvements during the winter [3,4] and a heating demand reduction in new and renovated dwellings. However, some of the energy-saving design strategies implemented came with limitations and negative impacts. For example, excessive internal heat caused by highly insulated and airtight structures without appropriate passive cooling strategies caused thermal discomfort of residents, as confirmed, e.g., by Badescu et al. [5] and Shrubsole et al. [6]. Overheating of the top stories of buildings frequently occurred [7-9]. During the summer season peak, ambient temperatures occasionally prohibit sufficient free cooling and require the use of mechanical cooling systems in very well-insulated buildings. Mechanical air conditioning devices (e.g., splits) are quite common in Mediterranean countries. However, active cooling 
is uncommon and not recommended for other European countries; therefore, the absence of adequate solar protection strategies and solutions for removing internal heat gains would result in frequent thermal discomfort during the summer [10].

Research conducted so far confirms the importance of this problem and its large scale $[8,11-21]$. The risk of overheating varies according to the typology of the residential building; for example, apartments with high roof exposures and high heat transfer coefficients overheat more often [12]. Other results from the Netherlands showed that most types of housing can effectively dampen the effects of global warming. However, poorly ventilated buildings are more prone to overheating and the most vulnerable to climate change, especially if their windows are not well protected from direct solar radiation [13]. Research conducted in Spain [21] observed a general deterioration of indoor thermal comfort conditions due to global warming, increasing the average percentage of discomfort hours in summer by more than 35\%. Touchie et al. [11] showed that residents who indicated the conditions "too warm" in surveys also reported frequent use of air conditioning and fans. Frequent use of mechanical systems results in high electricity consumption. Therefore, using passive measures that reduce solar heat gain and energy-saving cooling strategies to improve thermal comfort is highly recommended.

The main concept of passive cooling of a building involves using natural climate advantages to provide a healthier and more comfortable living environment [22]. One of the passive strategies is cooling with ventilation airflow, e.g., at night. The general trend towards less heating and greater cooling needs for buildings in many European countries resulted in the emergence of passive ventilative cooling as a promising technique, especially in commercial buildings in temperate to cold climates such as Central, Eastern, and North Europe [23]. Hamdy et al. [13] assessed the potential of ventilative cooling to mitigate the effects of climate change in the Netherlands. The combination of ventilation cooling and sun protection represents an effective adaptation measure to combat global warming. However, the potential of ventilative cooling decreases as global warming increases. Oropeza-Perez and Østergaard [24] investigated the potential of natural ventilation to improve indoor thermal comfort in Denmark. Their results showed a $90 \%$ time reduction in the use of mechanical ventilation, which indicated the potential of achieving thermal comfort in the building through the use of passive ventilative cooling.

Based on the most current literature, there is potential for improving energy efficiency in the residential building sector. Energy consumption in a building is influenced by all building external partitions, ventilation systems, and tenant behavior. Improving the thermal environment should be conducted with energy efficiency improvements in mind. A literature review (cited above) shows that residential buildings are more prone to overheating than other building types, and apartments on the top floors are more at risk of thermal discomfort than apartments on lower floors.

Thermal discomfort prompts people to change clothes or their environmental conditions [25], e.g., opening or closing windows [26]; therefore, this article sought to determine the cooling potential of this solution in a temperate Polish climate for existing, longstanding but modernized multi-family buildings. In the future, overheating is expected to increase in existing buildings due to the rise in outdoor temperature. Therefore, it is important to understand the impact of climate change on the risk of overheating, because as reports on the condition of large-panel construction in Poland [27] show, the technical condition of buildings is good and these facilities will remain in use for the next several dozen years. The results from this analysis should lead to the development of appropriate strategies to combat overheating in buildings. Additionally, in this study a mechanical outdoor air supply system controlled by both indoor and outdoor temperature was tested. This solution serves as an alternative to the opening and closing of windows which requires regular attention from residents. Its energy requirements are also low compared to air conditioning systems (e.g., splits). 


\section{Methods}

This study analyzed the influence of ventilation cooling on a multi-family building and used external airflow to improve the indoor thermal conditions and change the annual heat demand for dwellings of this type.

The research was conducted using EnergyPlus (for thermal calculations) [28] and CONTAM (for air exchange calculations) [29] simulation programs on the multi-zone model of the selected building fragment. EnergyPlus (EP) simulates the energy consumption and heat exchange throughout a building. In EnergyPlus, the implementation of the AFN (Airflow Network) module with a limited network airflow (AFN) allowed the calculation of the airflow between zones depending on pressure differences. This program was based on AIRNET [30], which was the forerunner and ensured the partial functionality of the current CONTAM version. The CONTAM program modeled airflow (natural ventilation) in this study due to its simplicity and the lack of some airflow model elements in AFN (such as the gravitational ventilation chimney model), available in CONTAM. The simulations utilized both programs (co-simulation), Figure 1; EnergyPlus is a leading program that automatically starts the numerical solver of the CONTAM program (ContamX). In the simplification, EnergyPlus calculated the temperature and ContamX calculated the airflows, and this connection utilized the FMI (FUNCTIONAL MOCK-UP Unit) standard [31].

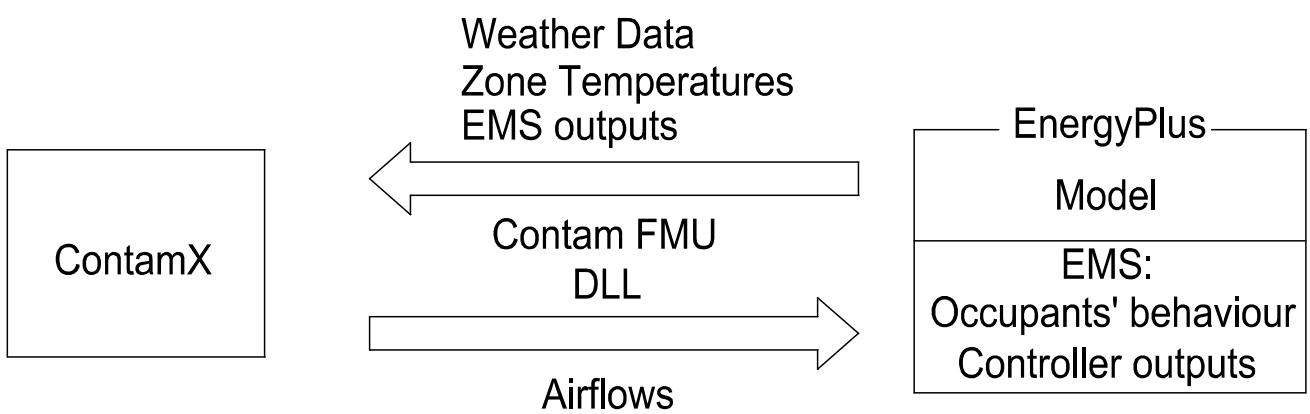

Figure 1. Connection diagram for EnergyPlus-CONTAM.

The boundary conditions for thermal comfort were calculated for the second environmental category according to an adaptive model [32]. As a measure of thermal comfort, the operative temperature was adopted and energy demand measured energy efficiency.

\subsection{Research Object}

A multi-family, five-story building located in Gliwice (southern Poland) was selected, and analyses were conducted on apartments located on the top two floors (Figure 2). Each floor consisted of three apartments with different areas-apartments 1, 2, and 3. Building construction took place in the 1960s and it features a reinforced concrete structure (prefabricated wall panel). External partitions have since been modernized (insulated) and the heat transfer coefficient changed from $U=0.75 \mathrm{~W} / \mathrm{m}^{2} \mathrm{~K}$ to $\mathrm{U}=0.20 \mathrm{~W} / \mathrm{m}^{2} \mathrm{~K}$ for external walls and from $U=0.63 \mathrm{~W} / \mathrm{m}^{2} \mathrm{~K}$ to $\mathrm{U}=0.15 \mathrm{~W} / \mathrm{m}^{2} \mathrm{~K}$ for the roof. The building contains typical double-glazed windows $\left(\mathrm{U}_{\text {glass }}=1.1 \mathrm{~W} / \mathrm{m}^{2} \mathrm{~K}\right.$ and the solar heat gain coefficient is 0.64$)$. The building comes with central heating and natural ventilation. 


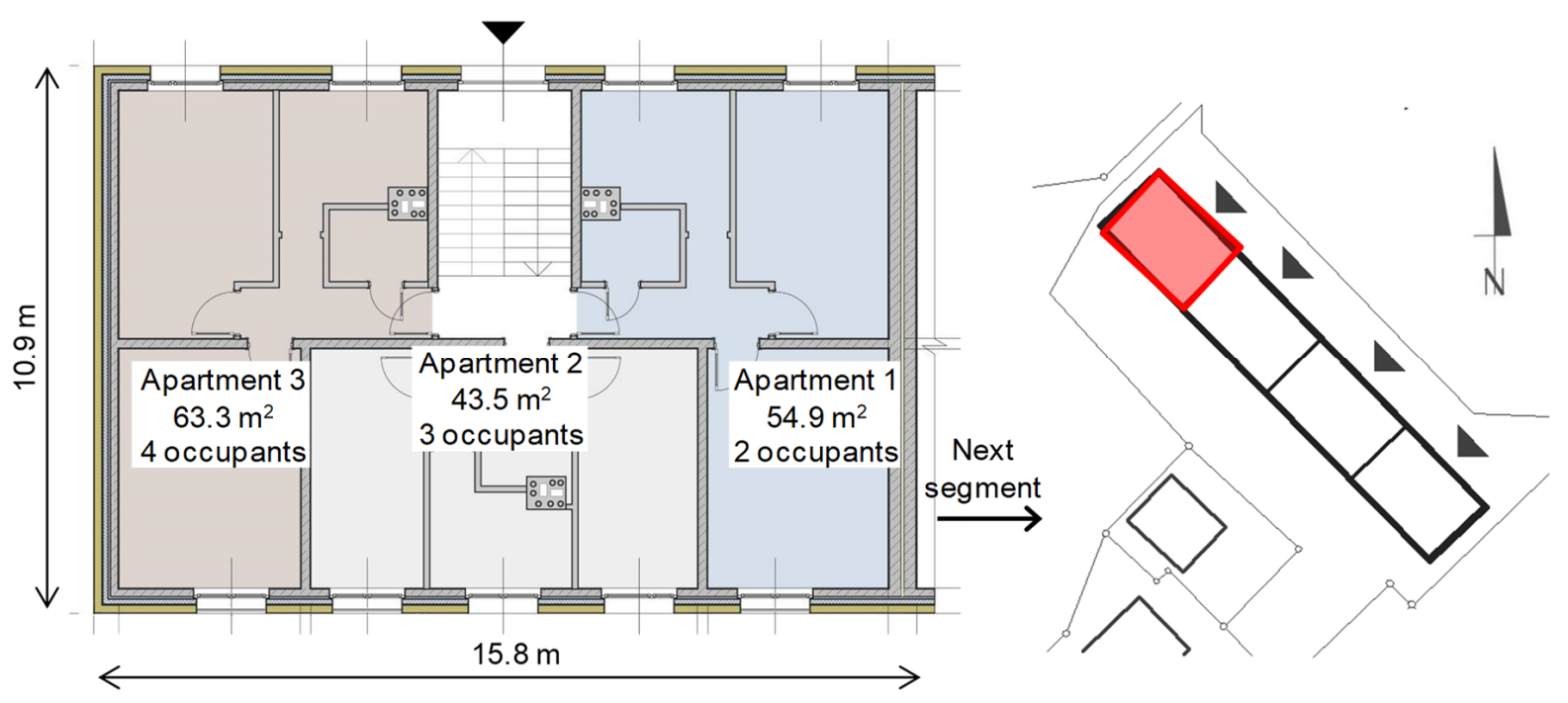

Figure 2. Floor plan.

\subsection{Thermal Model}

Each apartment was viewed as a separate thermal zone, which was used as an open space given their small sizes. In addition, it was very difficult to determine the behavior of residents controlling internal doors (opening, closing), which significantly impacts the air change rate for natural ventilation. Internal apartment partitions (e.g., partition walls) were considered as an additional internal mass.

The indoor apartment temperature from May to September was assumed as $21^{\circ} \mathrm{C}$ (the staircase, $16{ }^{\circ} \mathrm{C}$ ). The temperature set points remained constant during the day.

The total heat gains per person were set as $126 \mathrm{~W}$ during the day, with lower emissions during the evening due to sleep and lowered activity (set to $73 \mathrm{~W}$ ) [33]. Each apartment had an individual schedule which assumed it always contained at least one person, so the thermal comfort was calculated in apartments $24 \mathrm{~h}$ a day. The hourly schedules for the use of rooms were developed based on the experience of the authors and divided into working days and weekends. Heat load calculations included heat gains from people and electrical devices. The lighting power for each apartment was $3.5 \mathrm{~W} / \mathrm{m}^{2}$. Lighting was assumed as turned on when the lighting intensity was lower than $250 \mathrm{~lm} / \mathrm{m}^{2}$ (the lighting was turned off at night).

The model contained internal pull-down roller blinds on windows controlled manually by residents, operating ON-OFF. The shades were $\mathrm{ON}$ when the operative internal temperature exceeded the comfort temperature by $1.5 \mathrm{~K}$ and the solar radiation intensity (perpendicular to the window) exceeded $150 \mathrm{~W} / \mathrm{m}^{2}$. Additionally, the probability of 0.5 was assumed.

\subsection{Ventilation Model}

The model combined natural ventilation through leaks in the building with ventilation by opening windows and utilized the following boundary conditions:

- Indoor air temperature varied in time steps based on EP;

- Airflow was through the windows and two ventilation ducts in each apartment (kitchen and bathroom) and omitted any airflow between the apartments and the staircase;

- Window airtightness was based on the literature [34,35]. 


\subsubsection{Closed Windows: One-Way Flow Using POWERLAW Model}

There were three identical windows in the apartments and airflow was described using the following equations:

$$
\mathrm{V}=\mathrm{C} \times(\Delta \mathrm{p})^{\mathrm{n}},
$$

where:

V-airflow, $\mathrm{m}^{3} / \mathrm{h}$,

$\mathrm{n}$-exponent, $\mathrm{n}=0.67$ [36],

$\Delta \mathrm{p}$-pressure difference, $\mathrm{Pa}$,

C-flow coefficient, $\mathrm{m}^{3} /\left(\mathrm{h} \cdot \mathrm{Pa}^{\mathrm{n}}\right)$, defined as:

$$
\mathrm{C}=\mathrm{a} \times 1,
$$

where:

a-airtightness factor, $\mathrm{m}^{3} /\left(\mathrm{m} \cdot \mathrm{h} \cdot \mathrm{Pa}^{\mathrm{n}}\right), \mathrm{a}=0.3 \mathrm{~m}^{3} /\left(\mathrm{m} \cdot \mathrm{h} \cdot \mathrm{Pa}^{0.67}\right)$ was adopted,

1 - the length of the window cracks, $m$.

\subsubsection{Fully Open and Tilted Windows: Two-Way Flow Model (Single Opening)}

POWERLAW models allowed airflow in only one direction per step. Flows through larger openings (e.g., doors) tended towards greater complexity due to potential airflow in opposite directions at different parts of the opening. Therefore, this flow model type was chosen. Figure 3 lists the assumptions regarding the dimensions of fully open and tilted windows. For tilting windows, the opening area was calculated according to [37], and an alternate opening area was determined on both sides of the sash (as a rectangle $\mathrm{HxW}$ ).

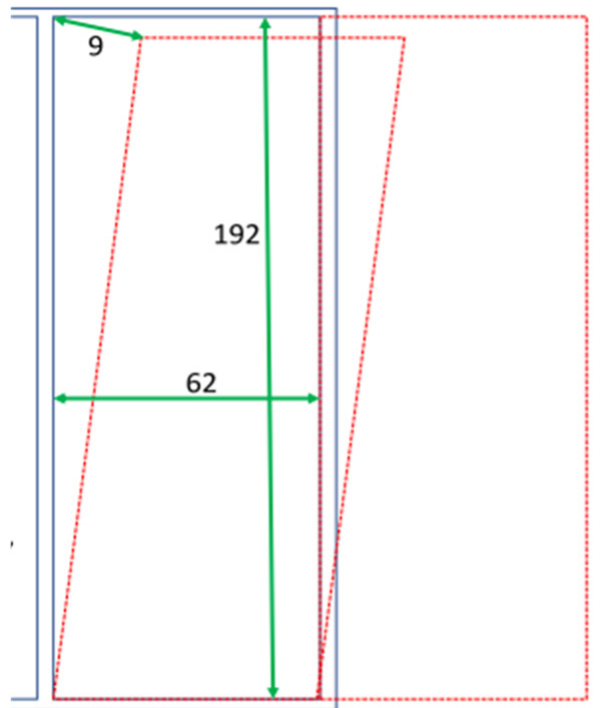

(a)

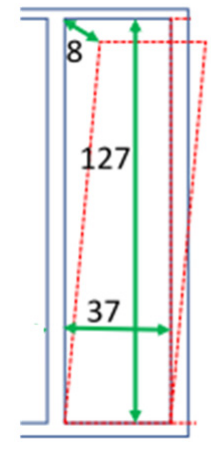

(b)

Figure 3. Opening areas in fully open and tilted windows (dimensions in $\mathrm{cm}$ ): balcony window (a), small windows (b).

\subsubsection{Gravitational Chimney: Darcy-Colebrook Resistance Model}

Gravitational chimneys were assumed as masonry, with a roughness of $3 \mathrm{~mm}$ and the sum of the local loss coefficients equal to 4.0 . The chimneys extended above the roof by $0.7 \mathrm{~m}$.

\subsection{Controlling the Opening of Windows-Stochastic Model}

The EnergyPlus program controlled opening the windows. Residents approached window control in different ways, and research conducted in this area primarily focused on 
office buildings which, due to the clearly defined usage period and ages of the workers (no children), were easier to model [38,39]. Previous studies divided the occupants according to their involvement into active, passive, and average [40,41]. A review of the methods used to model their behavior was published by Borgeson and Brager [42]. Researchers agree that human behavior is not deterministic, but stochastic. However, there is no agreement as to which parameters (e.g., internal or external temperature) have the greatest impact on the behavior of residents. In EnergyPlus, there is a stochastic model for window control in the AFN module. However, the only parameter that decides whether to open or close a window with a certain probability is the comfort temperature. As mentioned earlier, AFN was not used in this study (due to limitations).

The research proposed a novel model of window control. Residential behavior depended on the ambient temperature, indoor comfort temperature, wind speed, and the number of air change rates $(\mathrm{ACH})$. The last parameter limits the possibility of drafts in the apartment. Some window setting changes took place with a certain probability; for example, during the day, the probability was assumed as 0.5 , and 0.25 at night. Additionally, some deterministic constraints were introduced.

In the next part, there are symbols of optimized values for several variables marked with an $\mathrm{X}^{* *}$ (asterisks indicate a two-digit number). The daytime hours during the week were 7 a.m. to 10 p.m. and 8 a.m. to midnight on weekends. The remaining hours were night hours.

\subsubsection{Initial Restrictions}

Windows could be opened if: the wind speed was less than X01 m/s, the ambient temperature was lower than the indoor temperature, and the indoor operative temperature was $1.5 \mathrm{~K}$ higher than the optimal thermal comfort temperature. The window opening degree might be increased if the ambient temperature was lower than the indoor temperature and the operative temperature was $1.5 \mathrm{~K}$ above the comfort temperature.

\subsubsection{Restrictions in Window Control Regarding the Degree of Window Opening}

The research assumed that only the following degrees of window opening were possible:

1. Tilt the balcony window (the highest window in the apartment),

2. Tilt all windows,

3. Fully open the balcony window and tilt the rest of the windows.

\subsubsection{Restrictions in Window Control Regarding Time}

During the day it was possible (with probability) to open, close, and change the window position (increase the window opening degree $1 \rightarrow 2 \rightarrow 3$ or reduce it $3 \rightarrow 2 \rightarrow 1$ ). Any change that altered the window setting by either opening the window or changing the degree of opening required a minimum time interval of one hour. There was no such limitation for closing or reducing the degree of window opening.

At night, it was possible to reduce the degree of window opening or close it. However, a minimum of one hour had to pass between each operation. The window opening degree was not increased at night.

\subsubsection{Restrictions in Window Control Regarding Opening Degree}

The behavior of residents sought to maintain thermal comfort by limiting drafts and too rapid cooling of the apartment. Opening the window:

- $\quad$ To degree (1), if the wind speed was lower than X02 and the temperature difference between indoors and outdoors was smaller than X03;

- $\quad$ To degree (2), if the wind speed was within the range (X02, X04);

- To degree (3) in other cases.

Increasing the degree of window opening was possible if $\mathrm{ACH}<\mathrm{X} 05$ and the wind speed was lower than X06 for the change from $2 \rightarrow 3$ (analogously X07, X08 for $1 \rightarrow 2$ ). 
The window opening decreased by one degree if the ACH exceeded $\mathrm{X} 09$ and the indoor temperature dropped below $22{ }^{\circ} \mathrm{C}$. The window was closed when the ambient temperature exceeded the indoor temperature if the operative room temperature dropped $1.5 \mathrm{~K}$ below the operative comfort temperature, and the wind speed exceeded $10 \mathrm{~m} / \mathrm{s}$.

\subsubsection{Additional Restrictions}

Before sleeping (weekdays: 10:00 p.m. to 10:15 p.m., on weekends 11:45 p.m. to 00:00 a.m.):

- $\quad$ The window opening degree decreased from $3 \rightarrow 2$ if the ambient temperature was lower than X10, or the ACH exceeded X11;

- The degree of window opening was reduced by one degree if the ambient temperature was lower than X12 and if the difference between the comfort temperature and the operative temperature was less than X13.

Due to the different window opening settings in the outermost and middle apartments, two separate controllers were used for these apartments, respectively.

The controller described above was implemented in the EnergyPlus program through the EMS module. The calculated values were sent to the window controllers in the CONTAM program, where airflows were calculated.

\subsubsection{Optimization}

In the controller described in the previous section, symbols with values $X^{* *}$ were introduced. These are wind speeds, $\mathrm{ACH}$, temperatures, and temperature differences. A single controller contained 13 values. Real situations featured multiple years of experience involving resident inputs into window settings with certain climate parameter values. However, no such possibilities existed for simulation analyses, so these values were optimized using genetic algorithms from the MATLAB program. The version of the method implemented in this program was used for optimization.

Parameter optimization ensured an appropriate level of thermal comfort and assumed the parameter that describes the level of thermal comfort represents the number of hours the operative temperature remained in the zone outside the 2 nd zone of the internal environment for the adaptive thermal comfort model.

Proper window control must prevent excessive ventilation within the rooms. This may chill the rooms to the point that increases heat demand in the building (especially during yearly transition periods) and causes drafts in the apartments. Both factors are unfavorable. Only CFD models perform draft analyses and required a substitute solution. The permissible number of air change rates in the room was limited to $5 \mathrm{~h}^{-1}$. The strict control of this variable with the proposed control model gave a very conservative window control and, consequently, a large number of thermal discomfort hours. Therefore, the optimized parameters should be selected in such a way to minimize the number of thermal discomfort hours and hours when $\mathrm{ACH}>5 \mathrm{~h}^{-1}$. The described criterion fit the equation:

$$
\operatorname{Aim}=\min \left(\mathrm{H}_{\mathrm{dis}}+\mathrm{p} \times \mathrm{H}_{(\mathrm{ACH}>5)}\right)
$$

where:

$\mathrm{H}_{\text {dis }}$ - number of discomfort hours,

$\mathrm{H}_{(\mathrm{ACH}>5)}$-number of hours with $\mathrm{ACH}>5 \mathrm{~h}^{-1}$,

$\mathrm{p}$-penalty factor (assumption, $\mathrm{p}=10$ ).

The parameters obtained through optimization using genetic algorithms were entered into the controller programmed in the EMS part of the EnergyPlus program (for example, for apartments 02 and 12, the parameters were $X 01=5.5 \mathrm{~m} / \mathrm{s}, X 02=0.5 \mathrm{~m} / \mathrm{s}, X 03=4.5 \mathrm{~K}$, X04 = $4.5 \mathrm{~m} / \mathrm{s}$, X05 $=2 \mathrm{~h}^{-1}, \mathrm{X} 06=1.5 \mathrm{~m} / \mathrm{s}, \mathrm{X} 07=4 \mathrm{~h}^{-1}, \mathrm{X} 08=4 \mathrm{~m} / \mathrm{s}, \mathrm{X} 09=6 \mathrm{~h}^{-1}$, $\left.\mathrm{X} 10=15.5^{\circ} \mathrm{C}, \mathrm{X} 11=4.5 \mathrm{~h}^{-1}, \mathrm{X} 12=9{ }^{\circ} \mathrm{C}, \mathrm{X} 13=1.5 \mathrm{~K}\right)$. The optimization did not account for any stochastic behavior by the residents, introduced in the next step into the optimized model. In the analyses for models with opening windows, the results referred to the average 
of 10 simulations (the results in individual simulations differed due to the introduced stochastics). Only for $\mathrm{H}_{\text {dis }}$ was the range of results given.

\subsection{Climate}

The simulations were performed for a moderate transitional climate for the Katowice location closest to Gliwice. The analysis was conducted for two climate versions: a typical meteorological year (standard) [43] and a warmer climate, calculated based on global warming forecasts for 2050 (Figure 4). Each climate was characterized by different temperatures and solar radiation. In the standard climate adopted for the analyses, the minimum temperature was $-18.7^{\circ} \mathrm{C}$, the maximum was $31.0^{\circ} \mathrm{C}$, and the average annual temperature was $8{ }^{\circ} \mathrm{C}$. Using the CCWorldWeatherGen simulation program [44], the projected climate data for 2050 were calculated. The A2 emissions scenario was chosen and on the higher end of emission scenarios. However, preparing for and adapting to a larger climate change means any smaller climate change requires fewer measures for adoption and facilitates adaptation. The A2 scenario is one of the more popular scenarios in the literature [45]. In the warmer climate, the minimum temperature was $-13.9^{\circ} \mathrm{C}$, the maximum was $37.6^{\circ} \mathrm{C}$ and the average annual temperature was $11.0^{\circ} \mathrm{C}$.

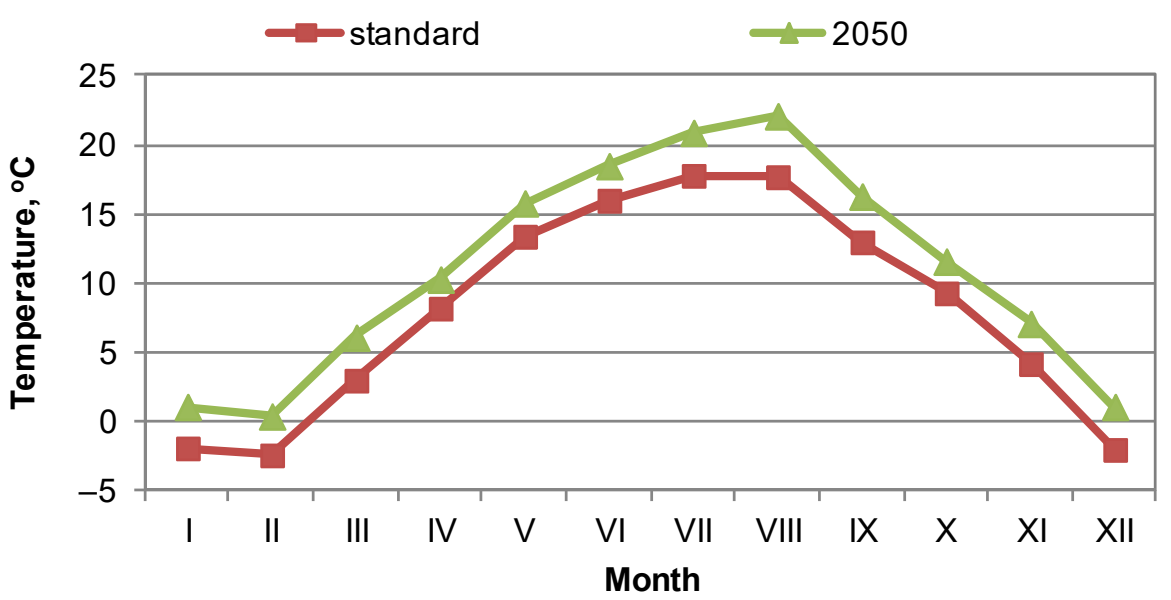

Figure 4. Average monthly outdoor temperatures for climates under consideration.

\subsection{Case Studies}

The following cases were considered:

- Natural ventilation plus window opening (base case).

- Mechanical supply and exhaust ventilation with heat recovery. The system provided a constant fresh airflow throughout the year $\left(\mathrm{CAV}\right.$, Constant Air Volume, $126 \mathrm{~m}^{3} / \mathrm{h}$ for each apartment). A $70 \%$ heat recovery efficiency was assumed. The airflow value was entered directly into EnergyPlus. The ventilation airflow was chosen in accordance with the EN-16798-1: 2019-06 standard [32]: $10 \mathrm{dm}^{3} / \mathrm{s}$ for the bathroom and $25 \mathrm{dm}^{3} / \mathrm{s}$ for the kitchen (the two main rooms in the apartment).

- Mechanical supply ventilation (VAV). The system provided a variable fresh airflow throughout the year (VAV, Variable Air Volume). The fans were modeled in CONTAM and intended for additional cooling of rooms with cooler outside air in the summer. The fans started automatically when the room temperature exceeded $24.5^{\circ} \mathrm{C}$ and the ambient temperature was lower than the indoor temperature and stopped at $23^{\circ} \mathrm{C}$. Two stages of operation were modeled: 1 st stage $-1.5 \times$ the standard airflow $\left(189 \mathrm{~m}^{3} / \mathrm{h}\right)$-if the difference between the indoor and outdoor temperature was higher than $20 \mathrm{~K}$; 2 nd stage $-3 \times$ standard airflow $\left(378 \mathrm{~m}^{3} / \mathrm{h}\right)$-in other cases. 


\section{Results}

The following symbols were adopted in the analyses: apartments on the penultimate floor A01, A02, and A03; apartments on the top floor A11, A12, and A13.

\subsection{The Effect of Additional Ventilation by Opening Windows and the Use of Internal Shades on Windows}

This section presents the impact of airing apartments by opening windows and the impact of internal roller shutters on heat demand, infiltration, and thermal comfort. The simulation results for the base model with window opening were compared to results for the base model without internal window shades and results for the theoretical (fictional) model without internal window shades and window opening. In real conditions, in the absence of a mechanical ventilation system, periodically opening windows always increased natural ventilation. However, this analysis showed some dependencies and the potential of the regular airing of apartments.

With closed windows, the average air change rate fluctuated $\sim 0.25 \mathrm{~h}^{-1}$, for rooms with a volume between 130 and $190 \mathrm{~m}^{3}$, and this resulted in a fresh airflow from $33-48 \mathrm{~m}^{3} / \mathrm{h}$ (Figure 5). The infiltration airflow was approximately three times lower than the standard. A smaller airflow of approximately $11 \mathrm{~m}^{3} / \mathrm{h}$ infiltrated the apartments on the top floor, which represents as much as a $30 \%$ decline. This is due to the shorter gravity chimney and smaller pressure difference. These differences practically disappear when opening the windows, which become the dominant airflow path.

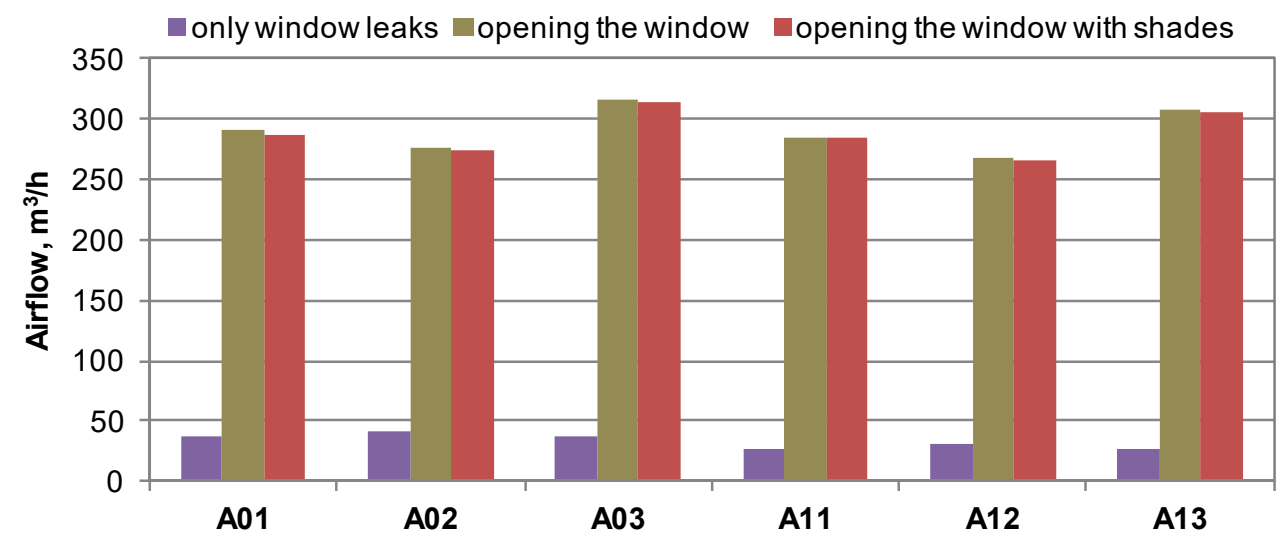

Figure 5. Average airflow in the apartments when the system is in operation (standard climate).

A significant improvement in apartment ventilation occurs upon opening the windows. The air change rates during opening windows in dwellings increased by a factor of nine. The amount of fresh air with the windows open increased on average to $\sim 200-280 \mathrm{~m}^{3} / \mathrm{h}$, twice as high as the minimum value required by the standard. The increased airflow increased the heat demand, as shown in Figure 6. The heat demand in the worst-case scenario increased by $27 \%$. However, airing the apartments had a huge impact on thermal comfort (Figure 7). For apartment A01, the number of thermal discomfort hours decreased by as much as $97 \%$. Natural ventilation, together with opening windows, requires duty and regularity from the occupants. Regarding mechanical ventilation, it is burdensome due to the amount of work required. These results were obtained considering non-ideal window control by the residents (this process was implemented by introducing probability into window control). If the opening of windows by residents was replaced by properly controlled sensors (opening probability $=1$ ), the number of discomfort hours dropped to 31-33 h, depending on the apartment (resident control increased this to 88-280 h). 


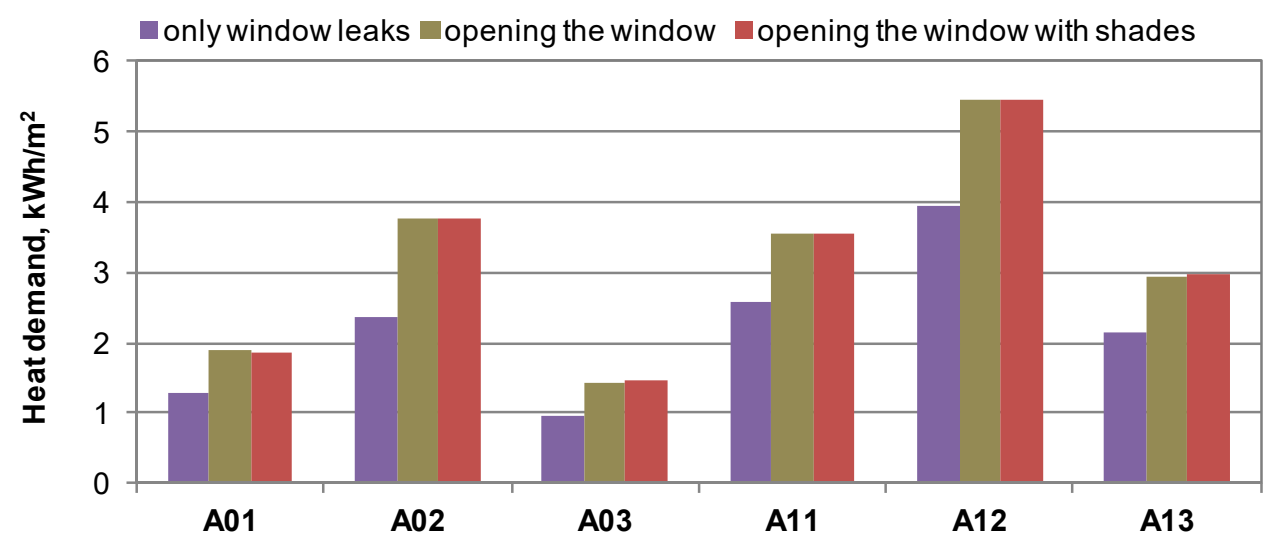

Figure 6. Annual heating demand (standard climate).

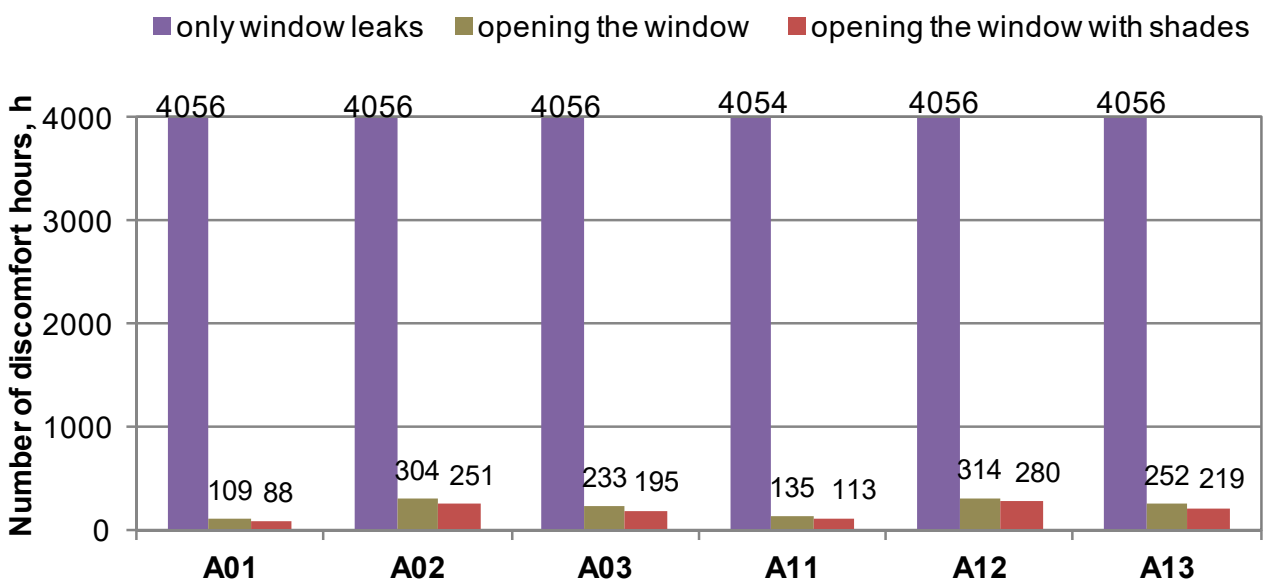

Figure 7. Thermal discomfort hours in apartments (standard climate).

On the other hand, the use of internal roller blinds on windows did not significantly change the heat demand; those differences ranged from $0.4 \%$ to $2.0 \%$. When using internal window shades, solar radiation entered the building, and the related heat gains entered the heat balance of the zones. In this case, the roller blinds operated in the ON-OFF mode, which occasionally led to switching on the lights and pulling down the shades. Additionally, in winter, when the heating system operated, window shades were used rather rarely. Therefore, the total annual heat balance with and without internal shading devices was very similar (for both the current and 2050 climates). The heat demand change for this climate ranged from $0.3 \%$ to $\sim 5 \%$. In turn, the presence of window shading had a much greater impact on the number of thermal discomfort hours. Its use reduced the $\mathrm{H}_{\text {dis }}$ by $11 \%$ to as much as $20 \%$ for a standard climate, but for a warmer climate, the improvement was only $4-8 \%$.

\subsection{Opening Windows vs. Mechanical Ventilation}

Figure 8 shows the average airflow supplied to the apartments during system operation times. When opening windows or operating VAV supply fans, the airflow was 2-3 times greater than the CAV system (which provides a hygienic amount of fresh air). Using mechanical ventilation with a constant ventilation airflow throughout the year (CAV), the heat demand increased in most apartments relative to natural ventilation and opening windows (Figure 9). In this case, the heat for ventilation increased despite using heat recovery. The winter airflow (when windows were not opened in the base case) was, on average, several times higher with mechanical ventilation. Providing higher air quality (by higher ventilation air exchange) comes with higher building operating costs. A significant increase in heat demand was recorded for the apartments on the top floor, where the infiltrating 
airflow in the base model with natural ventilation was the smallest. Apartment A02, the middle apartment and most prone to overheating, opened its windows the most often and resulted in the greatest heat demand. A similar tendency occurred in the warmer climate scenario. Unfortunately, with the CAV system, the number of discomfort hours increased drastically; in the standard climate case -18 times, and in a warmer climate- 2.5 times (Table 1). Supplying a constant amount of air has certain advantages such as higher air quality, but also comes with disadvantages such as higher outside air temperatures, which increases thermal discomfort.

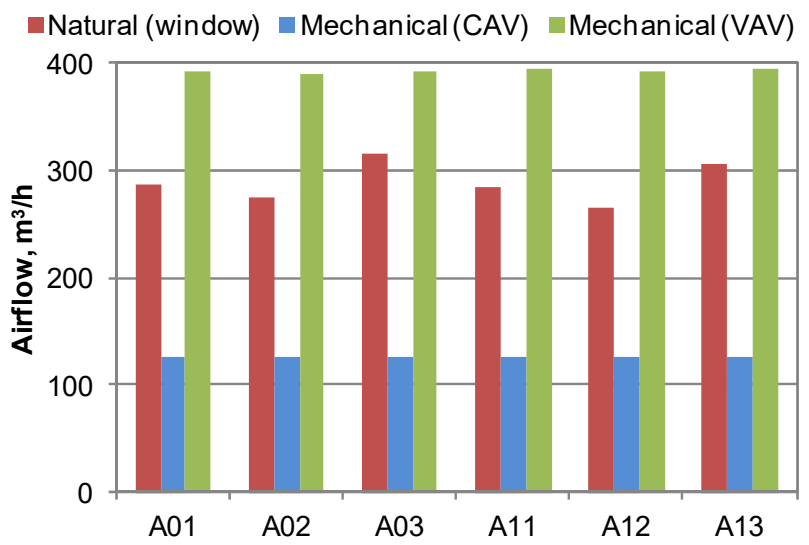

(a)

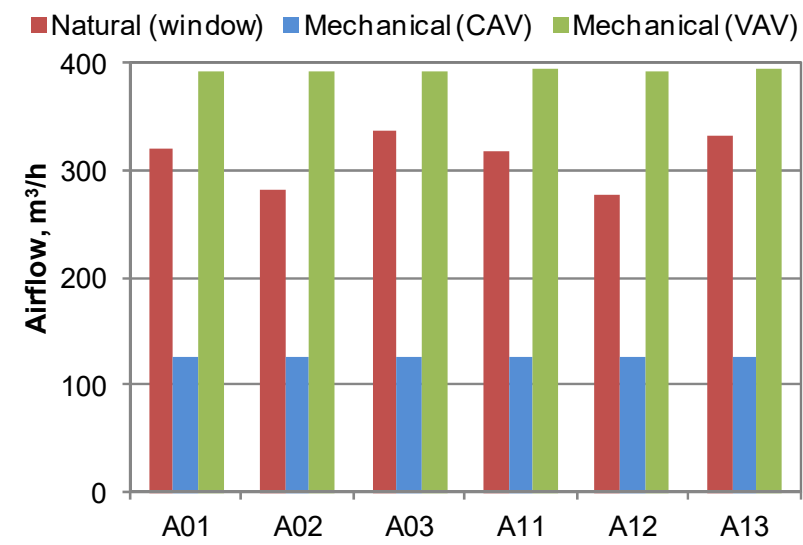

(b)

Figure 8. Ventilation airflow in dwellings for three cases of ventilative cooling: standard climate (a), warm climate (b).

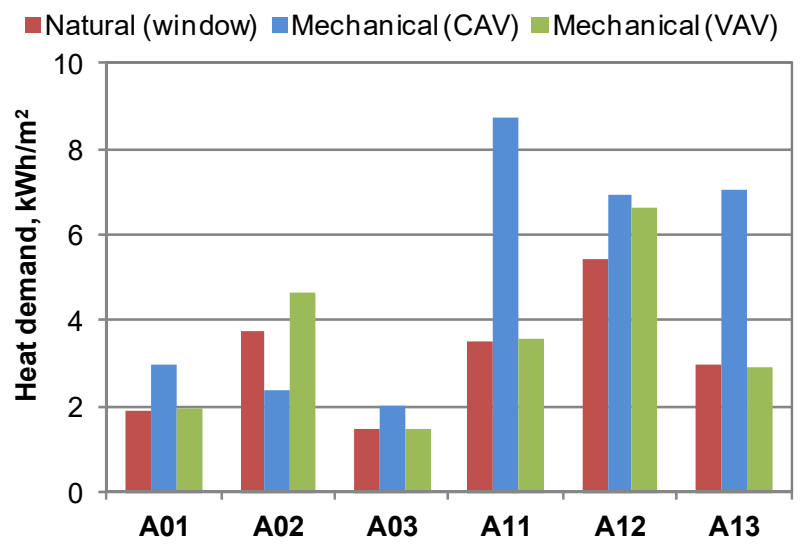

(a)

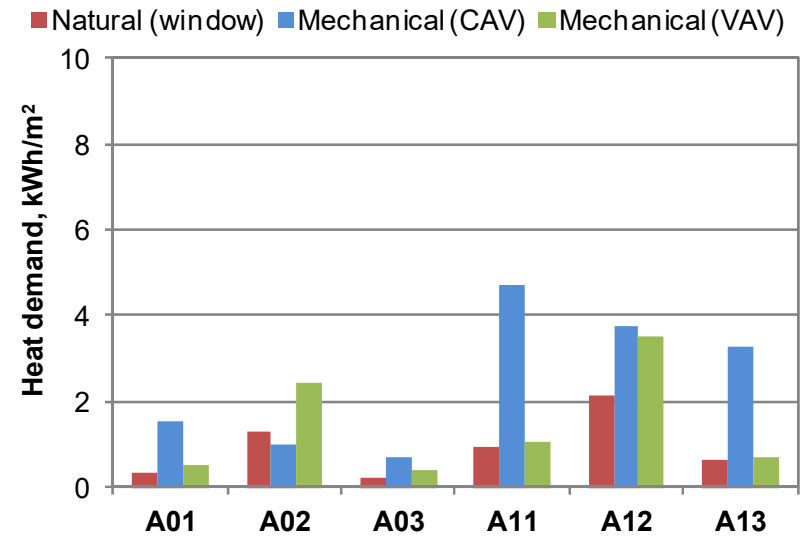

(b)

Figure 9. Annual heating demand in dwellings for three cases of ventilative cooling: standard climate (a), warm climate (b).

The use of VAV fans responsible for airing the apartments only with appropriate external conditions improved the thermal comfort for all apartments. Those results indicated a thermal comfort improvement for all apartments by $\sim 88 \%$ on average as compared to the window opening variant (with a very similar heat demand in the dwellings). Thermal comfort improvements for apartments on the top two floors were achieved. The impact of using fans to improve thermal comfort in a warmer climate was lower than in the standard climate, though the overall thermal comfort improvement was $~ 50 \%$. 
Table 1. Thermal discomfort hours in dwellings for three cases of ventilative cooling.

\begin{tabular}{|c|c|c|c|c|c|c|c|c|c|c|c|c|c|}
\hline \multirow{2}{*}{ Case } & \multicolumn{7}{|c|}{ Standard Climate } & \multicolumn{6}{|c|}{ Warm Climate } \\
\hline & & A01 & A02 & A03 & A11 & A12 & A13 & A01 & A02 & A03 & A11 & A12 & A13 \\
\hline \multirow{3}{*}{$\begin{array}{c}\text { Natural (by } \\
\text { window) }\end{array}$} & $\operatorname{avg}^{1}$ & 88 & 251 & 195 & 113 & 280 & 219 & 860 & 1145 & 1050 & 893 & 1181 & 1079 \\
\hline & $\max ^{2}$ & 112 & 274 & 230 & 140 & 305 & 258 & 903 & 1166 & 1086 & 950 & 1221 & 1110 \\
\hline & $\min ^{3}$ & 78 & 222 & 165 & 79 & 267 & 192 & 825 & 1123 & 1006 & 862 & 1159 & 1027 \\
\hline $\begin{array}{c}\text { Mechanical } \\
\text { (VAV) }\end{array}$ & & 4 & 45 & 28 & 10 & 39 & 34 & 369 & 504 & 604 & 436 & 545 & 640 \\
\hline $\begin{array}{c}\text { Mechanical } \\
(\mathrm{CAV})\end{array}$ & & 3034 & 3156 & 3170 & 2973 & 3070 & 3076 & 3602 & 3672 & 3646 & 3551 & 3605 & 3631 \\
\hline
\end{tabular}

${ }^{1}$ Average value of 10 simulations for the assumed probability. ${ }^{2}$ Maximum value of 10 simulations for the assumed probability. ${ }^{3}$ Minimum value of 10 simulations for the assumed probability.

The fans for both VAV and CAV systems required additional electricity. However, the VAV system fans operated between 32 and $37 \%$ of the year (depending on the apartment), mainly in the summer. The fans operated primarily during the 2nd stage, supplying apartments with maximum cooling airflow. Unfortunately, when opening windows, the airflow depends on natural conditions. In the evening, people do not always get up to close or open windows based on the current weather conditions. The mechanical VAV system avoids such limitations.

Climate warming reduces the annual heat demand (from 50-80\%), but it definitely worsens the possibilities of passive cooling. In a standard climate, the VAV system virtually eliminated thermal discomfort, and apartments on the top floor experienced thermal discomfort for a maximum of $39 \mathrm{~h}$ a year $(0.4 \%$ of the year). In a warmer climate, this system will not be able to provide thermal relief for $640 \mathrm{~h}$ on the top floor, which accounts for $7 \%$ of the year and $15 \%$ of the warm period. The situation is slightly better on the penultimate floor; those apartments do not suffer from additional summer heat provided by the "hot roof" (in the building under consideration, the roof is covered with black felt). The use of ventilation through a window in a warm climate means that more than $10 \%$ of the year is without thermal comfort (approx. 30\% of the period from May to September).

\section{Conclusions}

Climate change has a significant impact on both indoor thermal comfort conditions and the energy demand for heating and cooling (if any). This study:

- Demonstrated available solutions to reduce the negative impact of a warming climate on indoor conditions;

- Allowed the assessment of the potential of outdoor air cooling under conditions of variable external and internal heat loads;

- Compared the effect of people opening windows with automatically controlled systems.

The negative impacts of a warming climate and its consequences for living in buildings were presented as the number of thermal discomfort hours. Projections for a future warmer climate indicated a four-fold increase in the number of discomfort hours for apartments in multi-family buildings. This dependence equally affects apartments on the top and penultimate stories. Internal roller blinds, typically used in apartments, slightly reduce the number of times an apartment overheats. The shades are on the inside of the window and provide little insulation against solar radiation and external gains-the solar heat is transferred to the room. Internal blinds increase thermal comfort by approximately $15 \%$ and $6 \%$ for standard and 2050 climates, respectively. With an increasing average global temperature, the influence of internal blinds on thermal comfort conditions will decrease. Internal blinds can be a temporary solution, but their impact on improving indoor conditions decreases with climate change. 
Airing apartments by opening windows increases the heating demand, but brings very positive effects for thermal comfort and lowers the number of discomfort hours by over $90 \%$. The degree of airing depends on the occupants, and need not be as regular as it was in this work, which worsened the obtained effect. Additionally, it should be noted that this system provides a large amount of outdoor air that is not purified, which can be a problem in more polluted areas. Therefore, a mechanical outdoor airflow supply controlled by both indoor and outdoor temperatures (a VAV system) improves thermal comfort in summer with a low electricity demand that could come from photovoltaic panels located on the roof of the building.

Unfortunately, with the CAV mechanical ventilation system (working all day with constant airflow resulting from hygienic requirements), active air conditioning must be used in the summer to maintain the proper comfort levels. No airflow limitations on hot days cause a supply of hot air into the apartments, which exacerbates overheating problems and would require an automatic shut-off switch during such periods. Solar panels can power the CAV system only partially due to free space limitations on the roofs of multi-family buildings from chimneys and sewer vents.

Solutions to improve thermal comfort conditions in a warming climate should avoid the most popular solution so far-air-conditioning devices for apartments (splits with outdoor units located on balconies are an all-too-common solution routinely observed on residential buildings in Poland). These solutions automatically propel progressive climate change due to their excessive electricity (energy) needs. The cleanest form of energy is unused energy - eliminating the need for the electricity to power these air-conditioning systems drove the search for the solutions presented and analyzed in this article. To sum up, among the considered solutions, in the future, the best solution will be a mechanical outdoor air supply system with a variable ventilation airflow, allowing the use of air purifying filters (which is its additional advantage). However, disadvantages of additional noise generated by fans and electricity consumption (low, but still present) are not avoided.

\section{Future Research}

Future research efforts will examine and analyze the impacts of material and structural solutions, glazing, and external solar shades on the improvement of thermal comfort and energy consumption in apartments, as well as the effect of combining these solutions with passive cooling systems. The effects of the alternate use of passive and active thermal control technologies will also be explored.

Author Contributions: Conceptualization, J.F.-G., K.G. and A.G.; methodology, J.F.-G., K.G. and D.Ż.-T.; software, K.G.; formal analysis, J.F.-G., K.G., P.K., A.O., D.Z., R.P., J.S. and A.Z.; data curation, K.G., P.K., A.O., D.Z., R.P., J.S. and A.Z.; writing-original draft preparation, J.F.-G. and K.G.; writingreview and editing, D.Ż.-T.; project administration, A.G. All authors have read and agreed to the published version of the manuscript.

Funding: This research received no external funding.

Data Availability Statement: Not applicable.

Acknowledgments: This work was supported by the European Union from the European Social Fund in the framework of the project "Silesian University of Technology as a Center of Modern Education based on research and innovation" POWR.03.05.00-00-Z098/17 and the Polish Ministry of Science and Higher Education within a research subsidy.

Conflicts of Interest: The authors declare no conflict of interest. 


\section{References}

1. Statistics Poland. Energy Consumption in Households. 2018. Available online: https://stat.gov.pl/obszary-tematyczne/ srodowisko-energia/energia/zuzycie-energii-w-gospodarstwach-domowych-w-2018-roku,2,4.html (accessed on 15 May 2021). (In Polish)

2. National Energy Conservation Agency. A Handbook of Typology of Residential Buildings with Examples of Measures to Reduce Their Energy Consumption; NAPE: Warszawa, Poland, 2011; Available online: https://episcope.eu/fileadmin/tabula/public/docs/ brochure/PL_TABULA_TypologyBrochure_NAPE.pdf (accessed on 15 May 2021). (In Polish)

3. Hamilton, G.; Shipworth, I.D.; Summerfield, J.; Steadman, A.P.; Oreszczyn, T.; Lowe, R. Uptake of energy efficiency interventions in English dwellings. Build. Res. Inf. 2014, 42, 255-275. [CrossRef]

4. Porritt, S.; Cropper, P.; Shao, L.; Goodier, C. Ranking of interventions to reduce dwelling overheating during heat waves. Energy Build. 2012, 5, 16-27. [CrossRef]

5. Badescu, V.; Laaser, N.; Crutescu, R. Warm season cooling requirements for passive buildings in Southeastern Europe (Romania). Energy 2010, 35, 3284-3300. [CrossRef]

6. Shrubsole, C.; Macmillan, A.; Davies, M.; May, N. 100 unintended consequences of policies to improve the energy efficiency of the UK housing stock. Indoor Built Environ. 2014, 23, 340-352. [CrossRef]

7. Schünemann, C.; Olfert, A.; Schiela, D.; Gruhle, K.; Ortlepp, R. Mitigation and adaptation in multifamily housing: Overheating and climate justice. Build. Cities 2020, 1, 36-55. [CrossRef]

8. Sharifi, S.; Saman, W.; Alemu, A. Identification of overheating in the top-floor of energy-efficient multi-level dwellings. Energy Build. 2019, 204, 109452. [CrossRef]

9. Nebia, B.; Aoul, K.T. Overheating and daylighting; Assessment tool in early design of London's high-rise residential buildings. Sustainability 2017, 9, 1544. [CrossRef]

10. Ascione, F.; Böttcher, O.; Kaltenbrunner, R.; Vanoli, G.P. Methodology of the cost-optimality for improving the indoor thermal environment during the warm season. Presentation of the method and application to a new multi-storey building in Berlin. Appl. Energy 2015, 185, 1529-1541. [CrossRef]

11. Touchie, M.F.; Tzekova, E.S.; Siegel, J.A.; Purcell, B.; Morier, J. Evaluating Summertime Overheating in Multi-Unit Residential Buildings Using Surveys and In-Suite Monitoring. In Proceedings of the Thermal Performance of the Exterior Envelopes of Whole Buildings, XIII International Conference, Clearwater, FL, USA, 4-6 December 2016. Available online: https://taf.ca/wpcontent/uploads/2018/02/ASHRAE_TAF_Paper_MURB_Summer_Overheating_2016-10-31.pdf (accessed on 15 May 2021).

12. Gamero-Salinas, J.C.; Monge-Barrio, A.; Sánchez-Ostiz, A. Overheating risk assessment of different dwellings during the hottest season of a warm tropical climate. Build. Environ. 2020, 171, 106664. [CrossRef]

13. Hamdy, M.; Carlucci, S.; Hoes, P.-J.; Hensen, J.L.M. The impact of climate change on the overheating risk in dwellings-A Dutch case study. Build. Environ. 2017, 122, 307-323. [CrossRef]

14. Willand, N.; Ridley, I.; Pears, A. Relationship of thermal performance rating, summer indoor temperatures and cooling energy use in 107 homes in Melbourne, Australia. Energy Build. 2016, 113, 159-168. [CrossRef]

15. Birchmore, R.; Davies, K.; Etherington, P.; Tait, R.; Pavic, A. Overheating in Auckland homes: Testing and interventions in full-scale and simulated houses. Build. Res. Inform. 2016, 45, 157-175. [CrossRef]

16. Barbosa, R.; Vicente, R.; Santos, R. Climate change and thermal comfort in Southern Europe housing: A case study from Lisbon. Build. Environ. 2015, 92, 11. [CrossRef]

17. Dodoo, A.; Gustavsson, L. Energy use and overheating risk of Swedish multi-storey residential buildings under different climate scenarios. Energy 2016, 97, 534-548. [CrossRef]

18. Pathan, A.; Mavrogianni, A.; Summerfield, A.; Oreszczyn, T.; Davies, M. Monitoring summer indoor overheating in the London housing stock. Energy Build. 2017, 141, 361-378. [CrossRef]

19. Elsharkawy, H.; Zahiri, S. The significance of occupancy profiles in determining post retrofit indoor thermal comfort, overheating risk and building energy performance. Build. Environ. 2020, 172, 106676. [CrossRef]

20. Guo, H.; Huang, L.; Song, W.; Wang, X.; Wang, H.; Zhao, X. Evaluation of the summer overheating phenomenon in reinforced concrete and cross laminated timber residential buildings in the cold and severe cold regions of China. Energies 2020, $13,6305$. [CrossRef]

21. Escandón, R.; Suárez, R.; Sendra, J.J.; Ascione, F.; Bianco, N.; Mauro, G.M. Predicting the Impact of Climate Change on Thermal Comfort in A Building Category: The Case of Linear-type Social Housing Stock in Southern Spain. Energies 2019, $12,2238$. [CrossRef]

22. Homod, R.Z.; Almusaed, A.; Almssad, A.; Jaafar, M.K.; Goodarzi, M.; Saharif, K.S.M. Effect of different building envelope materials on thermal comfort and air-conditioning energy savings: A case study in Basra city, Iraq. J. Energy Storage 2021, 34, 101975. [CrossRef]

23. Artmann, N.; Manz, H.; Heiselberg, P. Climatic potential for passive cooling of buildings by night-time ventilation in Europe. Appl. Energy 2007, 84, 187-201. [CrossRef]

24. Oropeza-Perez, I.; Østergaard, P.A. Potential of natural ventilation in temperate countries—a case study of Denmark. Appl. Energy 2014, 114, 520-530. [CrossRef]

25. Nicol, J.F.; Humphreys, M. Adaptive Thermal Comfort: Principle and Practice; Earthscan: London, UK, 2012. 
26. Rijal, H.B.; Humphreys, M.A.; Nicol, J.F. Development of a window opening algorithm based on adaptive thermal comfort to predict occupant behavior in Japanese dwellings. Jpn. Archit. Rev. 2018, 1, 310-321. [CrossRef]

27. Building Research Institute. Large-Panel Construction-Report on Technical Condition; ITB: Warszawa, Poland, 2018. Available online: https:/ / budowlaneabc.gov.pl/budownictwo-wielkoplytowe-raport-o-stanie-technicznym (accessed on 15 May 2021). (In Polish)

28. Engineering Reference, EnergyPlus ${ }^{\mathrm{TM}}$ Version 8.7 Documentation; US Department of Energy: Washington, DC, USA, 2016. Available online: https://energyplus.net/sites/all/modules/custom/nrel_custom/pdfs/pdfs_v8.7.0/EngineeringReference.pdf (accessed on 15 May 2021).

29. Dols, W.S.; Polidoro, B.J. CONTAM User Guide and Program Documentation; Version 3.4; National Institute of Standards and Technology: Gaithersburg, MD, USA, 2020. Available online: https://nvlpubs.nist.gov/nistpubs/TechnicalNotes/NIST.TN.1887 r1.pdf (accessed on 15 May 2021).

30. Walton, G.N. AIRNET-A Computer Program for Building Airflow Network Modeling; NISTIR 89-4072; National Institute of Standards and Technology: Gaithersburg, MD, USA, 1989.

31. Blochwitz, T.; Otter, M.; Arnold, M.; Bausch, C.; Clauß, C.; Elmqvist, H.; Junghanns, A.; Mauss, J.; Monteiro, M.; Neidhold, T.; et al. The Functional Mockup Inter-face for Tool independent Exchange of Simulation Models. In Proceedings of the 8th International Modelica Conference, Dresden, Germany, 20-22 March 2011.

32. EU Standard EN16798-1:2019. Energy Performance of Buildings_Ventilation for Buildings_Part 1: Indoor Environmental Input Parameters for Design and Assessment of Energy Performance of Buildings Addressing Indoor Air Quality, Thermal Environment, Lighting and Acoustics-Module M1-6; European Committee for Standardization: Brussels, Belgium, 2019.

33. American Society of Heating, Refrigerating and Air Conditioning Engineers. ANSI/ASHRAE Standard 55-2017, Thermal Environmental Conditions for Human Occupancy; American Society of Heating, Refrigerating and Air Conditioning Engineers: Atlanta, GA, USA, 2017.

34. Blaszczok, M.; Baranowski, A. Thermal improvement in residential buildings in view of the indoor air quality-case study for Polish dwelling. Archit. Civ. Eng. Environ. 2018, 11, 121-130. [CrossRef]

35. Ferdyn-Grygierek, J.; Baranowski, A.; Blaszczok, M.; Kaczmarczyk, J. Thermal diagnostics of natural ventilation in buildings: An integrated approach. Energies 2019, 12, 4556. [CrossRef]

36. Awbi, H.B. Ventilation of Buildings; Spon Press: London, UK; Taylor \& Francis Group: New York, NY, USA, 2003.

37. Pinto, M.; Viegas, J.; Freitas, V. Summer cross ventilation in residential buildings. In Proceedings of the Energy for Sustainability International Conference 2017 Designing Cities \& Communities for the Future, Funchal, Portugal, 8-10 February 2017.

38. Haldi, F.; Robinson, D. A comprehensive stochastic model of window usage: Theory and validation. In Proceedings of the Eleventh International IBPSA Conference, Glasgow, Scotland, 27-30 July 2009.

39. Dutton, S.; Zhang, H.; Zhai, Y.; Arens, E.; Bennani Smires, Y.; Brunswick, S.; Konis, K.; Haves, P. Application of a stochastic window use model in EnergyPlus. In Proceedings of the SimBuild 2012, 5th National Conference of IBPSA, Madison, WI, USA, 1-3 August 2012.

40. D'Oca, S.; Fabi, V.; Corgnati, S.P.; Andersen, R.K. Effect of thermostat and window opening occupant behavior models on energy use in homes. Build. Simul. 2014, 7, 683-694. [CrossRef]

41. Fabi, V.; Anderson, R.K.; Corgnati, S.P.; Vanezia, F. Influence of user behaviour on indoor environmental quality and heating energy consumptions in Danish dwellings. In Proceedings of the 2nd International Conference on Building Energy and Environment (COBEE), Boulder, CO, USA, 1-4 August 2012.

42. Borgeson, S.; Brager, G. Occupant Control of Windows: Accounting for Human Behavior in Building Simulation; Center for the Built Environment; University of California: Berkeley, CA, USA, 2008. Available online: https://escholarship.org/uc/item/5gx2n1zz\# main (accessed on 15 May 2021).

43. EnergyPlus Weather File. Available online: https:/ / energyplus.net/weather (accessed on 15 May 2021).

44. University of Southampton. Climate Change World Weather File Generator for World-Wide Weather Data-CCWorldWeatherGen. Available online: http:/ / www.energy.soton.ac.uk/ccworldweathergen/ (accessed on 15 May 2021).

45. Verichev, K.; Zamorano, M.; Carpio, M. Effects of climate change on variations in climatic zones and heating energy consumption of residential buildings in the southern Chile. Energy Build. 2020, 215, 109874. [CrossRef] 